УДК 666.9.015

Д-р техн. наук Л.Й. Дворкін, канд. техн. наук Ю.В. Гарніцький, acn. В.В. Марчук, студ. І.В. Фірсов (НУВГП)

L.I. Dvorkin, Y.V. Harnitskij, V.V. Marchuk, I.V. Firsov

\title{
ОПТИМІЗАЦІЯ РЕЖИМІВ ТЕПЛОВОЛОГІСНОЇ ОБРОБКИ БЕТОНІВ НА ОСНОВІ ЗОЛОВМІСНИХ ЦЕМЕНТІВ НИЗЬКОЇ ВОДОПОТРЕБИ
}

\section{OPTIMIZATION OF CURING CONDITIONS OF CONCRETE, BASED ON THE CEMENTS OF LAW WATER DEMAND USING FLY-ASH}

\begin{abstract}
Важливим
технологічним

процесом, який впливає на структуру й експлуатаційні властивості бетонних та залізобетонних конструкцій $\epsilon$ тепловологісна обробка (ТВО). Ця технологічна стадія в сучасних умовах $\epsilon$ ефективним методом прискорення твердіння, що забезпечує скорочення процесу виробництва та підвищення продуктивності. Вона багато в чому зумовлює кінцеві фізико-механічні властивості бетону, і застосування певних режимів дозволяє в тій чи іншій мірі керувати процесами структуроутворення. Це особливо важливо для бетонів виробів, до яких ставляться підвищені вимоги за довговічністю, наприклад для дорожнього чи водогосподарського будівництва. $\mathrm{y}$ цьому випадку слід застосовувати "м'які", низькотемпературні режими, і в той же час необхідно досягти достатньої розпалубочної і передаточної міцності.

Як відомо, теплова обробка значною мірою прискорює твердіння бетонів на малоактивних цементах, ніж на в'яжучих підвищеної активності. Однак у заводському виробництві для одержання максимально можливої абсолютної міцності бетону в короткі терміни доцільно застосовувати швидкотверднучі цементи та цементи підвищених марок. Тому досить
\end{abstract}

ефективними можуть бути цементи низької водопотреби (ЦНВ) 3 нормальною густотою цементного тіста $17 . .19 \%$. Використання ЦНВ дозволяє економити до $70 \%$ найбільш дорогого компоненту портландцементу - клінкеру, або, при потребі, збільшувати міцнісні показники [1, 2]. Бетони на основі пропонованого в'яжучого характеризуються високою морозостійкістю, водонепроникністю і тріщиностійкістю. Їх водопоглинання нижче, ніж у звичайних бетонах в 2,02,5 рази, а деформація усадки і повзучості на 10-20\% [1]. Ці фактори обумовлюють високу довговічність конструкцій 3 використанням таких бетонів. Найвища активність ЦНВ та міцність бетонів на їх основі були отримані при використанні у цементі поряд 3 клінкером активних мінеральних добавок - доменного шлаку та золи-виносу [2,3]. Застосування золи-виносу доцільне також через те, що іiі висока дисперсність та розмелююча здатність суттєво знижують енергозатрати на помел.

Оскільки ЦНВ належить до швидкотверднучих в'яжучих, то відомі на сьогодні їх дослідження проводилися тільки при твердінні в нормальних умовах. Однак, на наш погляд, цікаво було б дослідити особливості твердіння ЦНВ в умовах ТВО, тому що це може бути 
використано як резерв підвищення міцності або можливого подальшого зниження вмісту клінкеру, що дозволить ще більше здешевити пропоновані в'яжучі. При цьому найбільш доцільними $є$ низькоенергоємні режими ТВО.

Метою даної роботи було встановлення оптимальних параметрів режиму TBO, а також його вплив на кінетику набору міцності й експлуатаційні властивості бетонів на основі золовмісних ЦНВ. вували:

Як вихідні матеріали використо-

- як компоненти ЦНВ: портландцемент ПЦ II/A-Ш-500 з таким мінералогічним складом клінкеру: $\mathrm{C}_{3} \mathrm{~S}-57,1 \% ; \mathrm{C}_{2} \mathrm{~S}-$ $21,27 \% ; \mathrm{C}_{3} \mathrm{~A}-6,87 \% ; \mathrm{C}_{4} \mathrm{AF}-12,19 \%$; золу-виносу Бурштинської ТЕС, комплексний модифікатор у складі: суперпластифікатор (СП) полікарбоксилатного типу SikaViscoCrete 225 та інтенсифікатор помелу - пропіленгліколь;

- крупний заповнювач - базальтовий щебінь $3 \mathrm{D}_{\text {макс }}=20 \mathrm{Mм}$,

- дрібний заповнювач - кварцовий пісок з $\mathrm{M}_{\mathrm{K}}=1,9$.

3 урахуванням речовинного складу портландцементу склад отриманого в'яжучого був такий: клінкер - $50 \%$, шлак $12 \%$, зола-виносу - $38 \%$, СП - 0,4...1,0\%, пропіленгліколь - 0,04\%.

3 метою досягнення заданого рівня значущості при мінімальній кількості дослідів використовували математичне планування експерименту. Був реалізований трирівневий чотирифакторний план $\mathrm{B}_{4}$ [4], умови планування якого наведені в табл. 1.

Таблиця 1

Умови планування експерименту

\begin{tabular}{|l|c|c|c|c|c|}
\hline \multicolumn{2}{|c|}{ Фактори впливу } & \multicolumn{3}{c|}{$\begin{array}{c}\text { Piвні варіювання } \\
\text { факторів }\end{array}$} & $\begin{array}{c}\text { Інтер- } \\
\text { вал } \\
\text { варію- } \\
\text { вання }\end{array}$ \\
\cline { 1 - 5 } Натуральний вид & $\begin{array}{c}\text { Кодова- } \\
\text { ний вид }\end{array}$ & -1 & 0 & +1 & 0,3 \\
\hline Вміст добавки СП у ЦНВ, \% & $\mathrm{X}_{1}$ & 0,4 & 0,7 & 1,0 & 0,3 \\
\hline Водоцементне відношення В/Ц & $\mathrm{X}_{2}$ & 0,25 & 0,3 & 0,35 & 0,05 \\
\hline Час ізотермічної витримки, $\tau_{\text {iз }}$, год & $\mathrm{X}_{3}$ & 4 & 6 & 8 & 2 \\
\hline Максимальна температура $\mathrm{T}_{\mathrm{i}},{ }^{0} \mathrm{C}$ & $\mathrm{X}_{4}$ & 60 & 75 & 90 & 15 \\
\hline
\end{tabular}

У ході досліджень у кожній точці плану для оцінки впливу факторів та ефективності ТВО на міцність бетонів виготовляли стандартні зразки-куби (10x10 см), які тверділи у нормальних умовах. Водопотреба бетонної суміші в усіх точках була однаковою. Теплова обробка проводилась у лабораторній пропарювальній камері за таким режимом: попереднє витримування - 2 год; піднімання температури зі швидкістю $25^{\circ} \mathrm{C} /$ год; ізотермічна витримка - згідно 3 умовами планування (табл. 1); «термосне» охолодження. Після ТВО визначали міцність зразків на стиск через 4 год та у віці 28 діб, а також зразків, які тверділи без TBO.

Матриця планування та отримані експериментальні результати наведені в табл. 2. У графі 10 зазначена витрата портландцементного клінкеру на $1 \mathrm{~m}^{3}$ бетону, а в графі 11 - ii відношення до міцності бетону після ТВО. Цей показник можна вважати одним із критеріїв енергоефективності бетону в цілому [5] та режиму його ТВО зокрема. 
Будівельні матеріали, конструкції та споруди

Таблиця 2

Матриця планування та експериментальні результати

\begin{tabular}{|c|c|c|c|c|c|c|c|c|c|c|}
\hline \multirow{2}{*}{$\begin{array}{l}\text { № } \\
\Pi / \Pi\end{array}$} & \multicolumn{4}{|c|}{ Фактори впливу } & \multirow{2}{*}{$\begin{array}{l}\text { Рухли- } \\
\text { вість* }\end{array}$} & \multicolumn{3}{|c|}{$\begin{array}{c}\text { Міцність на стиск, МПа у } \\
\text { віці: }\end{array}$} & \multirow{2}{*}{$\begin{array}{c}\text { Витрата } \\
\text { клінкеру } \\
(\text { Кл), } \\
\text { кг/м }\end{array}$} & \multirow{2}{*}{$\begin{array}{l}\frac{K_{л}}{\mathrm{R}_{\text {тво }}}, \\
\text { кг/MПа }\end{array}$} \\
\hline & $\begin{array}{c}\mathrm{C} \Pi, \\
\%\end{array}$ & $\frac{\text { В }}{Ц}$ & $\begin{array}{l}\mathrm{T}_{\mathrm{i}}, \\
\text { год }\end{array}$ & ${ }^{\mathrm{t}_{13}}$ & & $\begin{array}{c}4 \text { год } \\
\text { після } \\
\text { ТВО }\end{array}$ & $\begin{array}{c}28 \text { діб } \\
\text { після } \\
\text { ТВО }\end{array}$ & $\begin{array}{l}28 \text { діб } \\
\text { НТ** }^{*}\end{array}$ & & \\
\hline 1 & 2 & 3 & 4 & 5 & 6 & 7 & 8 & 9 & 10 & 11 \\
\hline 1 & 1,0 & 0,35 & 8 & 90 & PK 60 & 57,3 & 59,0 & 43,0 & 160 & 2,8 \\
\hline 2 & 1,0 & 0,35 & 8 & 60 & PK 59,5 & 52,8 & 56,0 & 42,8 & 160 & 3,0 \\
\hline 3 & 1,0 & 0,35 & 4 & 90 & PK 58,5 & 55,1 & 57,6 & 44,9 & 160 & 2,9 \\
\hline 4 & 1,0 & 0,35 & 4 & 60 & PK 59 & 47,9 & 56,9 & 41,8 & 160 & 3,3 \\
\hline 5 & 1,0 & 0,25 & 8 & 90 & PK 50 & 77,6 & 81,5 & 68,8 & 260 & 3,4 \\
\hline 6 & 1,0 & 0,25 & 8 & 60 & PK 50,5 & 71,9 & 79,0 & 68,1 & 260 & 3,6 \\
\hline 7 & 1,0 & 0,25 & 4 & 90 & PK 49 & 74,0 & 80,1 & 68,8 & 260 & 3,5 \\
\hline 8 & 1,0 & 0,25 & 4 & 60 & PK 49,5 & 70,1 & 77,4 & 67,3 & 260 & 3,7 \\
\hline 9 & 0,4 & 0,35 & 8 & 90 & $\mathrm{OK} 5,5$ & 56,2 & 60,6 & 44,9 & 160 & 2,8 \\
\hline 10 & 0,4 & 0,35 & 8 & 60 & OK 5 & 51,4 & 60,2 & 43,9 & 160 & 3,1 \\
\hline 11 & 0,4 & 0,35 & 4 & 90 & OK 5,5 & 53,4 & 60,7 & 44,7 & 160 & 3,0 \\
\hline 12 & 0,4 & 0,35 & 4 & 60 & OK 6 & 47,9 & 59,1 & 44,2 & 160 & 3,3 \\
\hline 13 & 0,4 & 0,25 & 8 & 90 & Ж 3 & 80,0 & 82,1 & 71,2 & 260 & 3,3 \\
\hline 14 & 0,4 & 0,25 & 8 & 60 & Ж 4 & 74,6 & 80,2 & 70,5 & 260 & 3,5 \\
\hline 15 & 0,4 & 0,25 & 4 & 90 & Ж 5 & 77,9 & 80,1 & 70,8 & 260 & 3,3 \\
\hline 16 & 0,4 & 0,25 & 4 & 60 & Ж 4 & 72,8 & 78,9 & 70,2 & 260 & 3,6 \\
\hline 17 & 1,0 & 0,3 & 6 & 75 & PK 55 & 56,3 & 64,2 & 54,5 & 216 & 3,8 \\
\hline 18 & 0,4 & 0,3 & 6 & 75 & OK 3 & 57,1 & 65,1 & 55,0 & 216 & 3,8 \\
\hline 19 & 0,7 & 0,35 & 6 & 75 & OK 13 & 50,5 & 60,2 & 44,3 & 160 & 3,2 \\
\hline 20 & 0,7 & 0,25 & 6 & 75 & OK 7 & 74,3 & 78,5 & 69,2 & 260 & 3,5 \\
\hline 21 & 0,7 & 0,3 & 8 & 75 & $\mathrm{OK} 10,5$ & 60,0 & 66,3 & 55,1 & 216 & 3,6 \\
\hline 22 & 0,7 & 0,3 & 4 & 75 & OK 10,5 & 58,4 & 65,2 & 55,6 & 216 & 3,7 \\
\hline 23 & 0,7 & 0,3 & 6 & 90 & OK 11 & 62,4 & 66,2 & 56,5 & 216 & 3,5 \\
\hline 24 & 0,7 & 0,3 & 6 & 60 & OK 10 & 58,1 & 62,9 & 55,0 & 216 & 3,7 \\
\hline
\end{tabular}

* - РК - розпливання конуса, см; ОК - осідання конуса, см; Ж - жорсткість, с.

** - зразки нормального твердіння.

Після обробки й статистичного аналізу експериментальних даних отримали рівняння регресії міцності пропареного бетону:

- через 4 год після ТВО:

$$
\begin{gathered}
\mathrm{R}_{\text {ст }}{ }^{\text {ТВO }}=58,3-0,46 \cdot \mathrm{x}_{1}-11,24 \cdot \mathrm{x}_{2}+1,36 \cdot \mathrm{x}_{3}+2,6 \cdot \mathrm{x}_{4}+0,8 \cdot \mathrm{x}_{1} \mathrm{x}_{2}+0,14 \cdot \mathrm{x}_{1} \mathrm{x}_{3}+0,26 \cdot \mathrm{x}_{2} \mathrm{x}_{3}- \\
-1,7 \cdot \mathrm{x}_{1}{ }^{2}+4,0 \cdot \mathrm{x}_{2}{ }^{2}+0,8 \cdot \mathrm{x}_{3}{ }^{2}+1,85 \cdot \mathrm{x}_{4}{ }^{2} ;
\end{gathered}
$$

- у віці 28 діб:

$$
\begin{aligned}
\mathrm{R}_{\mathrm{cr}}{ }^{28}= & 65,04+0,46 \cdot \mathrm{x}_{1}-10,5 \cdot \mathrm{x}_{2}+0,5 \cdot \mathrm{x}_{3}+0,97 \cdot \mathrm{x}_{4}-0,49 \cdot \mathrm{x}_{1} \mathrm{x}_{2}+0,24 \cdot \mathrm{x}_{1} \mathrm{x}_{4}- \\
& -0,3 \cdot \mathrm{x}_{2} \mathrm{x}_{3}-0,16 \cdot \mathrm{x}_{2} \mathrm{x}_{4}-0,5 \cdot \mathrm{x}_{1}{ }^{2}+4,2 \cdot \mathrm{x}_{2}{ }^{2}+0,6 \cdot \mathrm{x}_{3}{ }^{2}-0,6 \cdot \mathrm{x}_{4}{ }^{2} .
\end{aligned}
$$


Графічні залежності міцності пропареного бетону на основі золовмісних ЦНВ від технологічних факторів через 4 год. після ТВО наведені на рис. 1, а у віці 28 діб - на рис. 2.

Їх аналіз дозволяє розмістити фактори впливу у такий ряд за значущістю: $\mathrm{x}_{2}>\mathrm{x}_{4}>\mathrm{x}_{3}>\mathrm{x}_{1}$. Як і очікувалось, найбільш впливовим $\epsilon$ фактор В/Ц, однак простежується його деяка взаємодія 3 параметрами теплової обробки тривалістю та максимальною температурою. Серед цих двох факторів температура $\epsilon$ більш впливовою, однак збільшення тривалості ізотермічної витримки на 2 год дозволяє компенсувати зниження максимальної температури на $15^{0} \mathrm{C}$ (точки 22 і 24 ) за інших рівних умов.
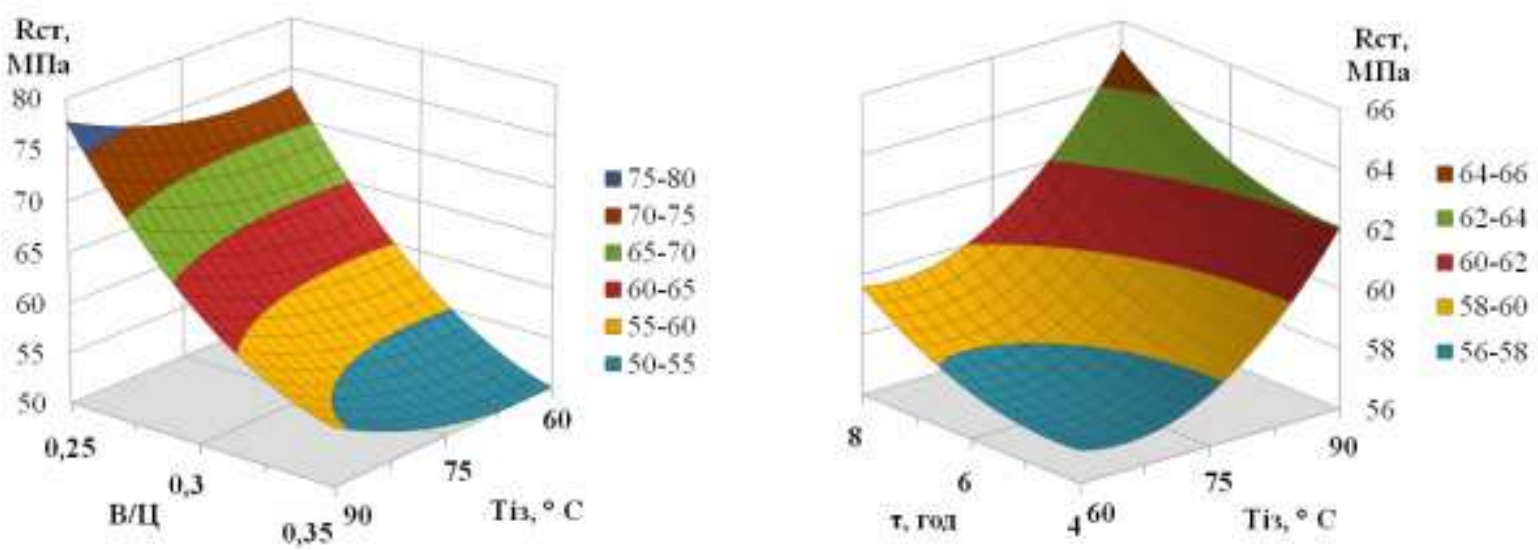

Рис. 1. Вплив технологічних факторів на міцність бетону на основі золовмісних ЦНВ після ТВО
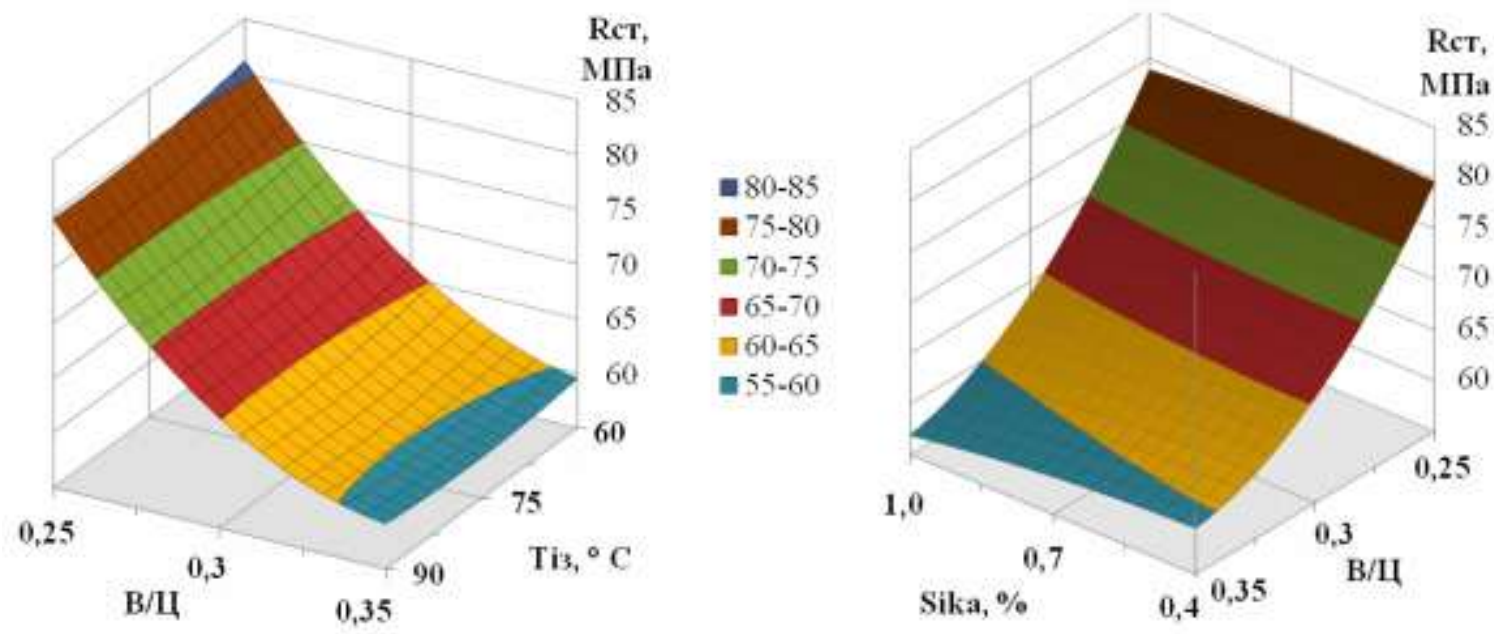

Рис. 2. Вплив технологічних факторів на міцність пропареного бетону у віці 28 діб на основі золовмісних ЦНВ

У випадку збільшення ізотермічної витримки 34 до 8 год спостерігаємо зростання міцності в межах $10 \ldots 15 \%$, так само, як і при збільшенні температури ТВО на $25 . .30{ }^{0} \mathrm{C}$. Слід урахувати, що підвищення температури ТВО більш суттєво підвищує енергозатрати, ніж збільшення тривалості, до того ж "м'які" 
режими необхідні з точки зору підвищення довговічності виробів. Підвищення кількості суперпластифікатора у в'яжучому з 0,4 до $0,7 \ldots 1,0 \%$ може супроводжуватись незначним зниженням міцності пропареного бетону (рис.2), але при цьому отримуємо суміші литої консистенції 3 розпливанням конуса до $60 \mathrm{~cm}$, що $\epsilon$ позитивним моментом при виготовленні сучасних високотехнологічних бетонів, здатних до самоущільнення.

У віці 28 діб міцність бетону 3 різними режимами ТВО практично вирівнюється за інших рівних умов. Міцність зразків нормального твердіння в усіх випадках нижча, ніж пропарених (до $25 \%$ навіть при низькотемпературних режимах ТВО. Це можна пояснити більш суттєвою інтенсифікацією процесів твердіння під час ТВО бетонів на основі золовмісних ЦНВ, ніж бетонів на звичайних портландцементах. Для оцінки ефективності використання цементного клінкеру в пропареному бетоні можна використати відношення його витрати на $1 \mathrm{~m}^{3}$ бетону до міцності бетону через 4 год після ТВО (кілограм на мегапаскаль). Зменшення цього показника свідчить про вищу ефективність використання клінкеру. Для бетонів міцністю 35-40 МПа нормального твердіння цей критерій, як правило, знаходиться в межах $12 \ldots 14$ [5], для бетонів міцністю 60-80 МПа 3 використанням сучасних суперпластифікаторів i мікрокремнезему 7...10. Для досліджених складів зазначений коефіцієнт лежить у межах 2,8...3,8 (табл. 2 та рис. 3), що свідчить про високу ефективність ТВО при використанні в бетоні золовмісних цементів низької водопотреби.

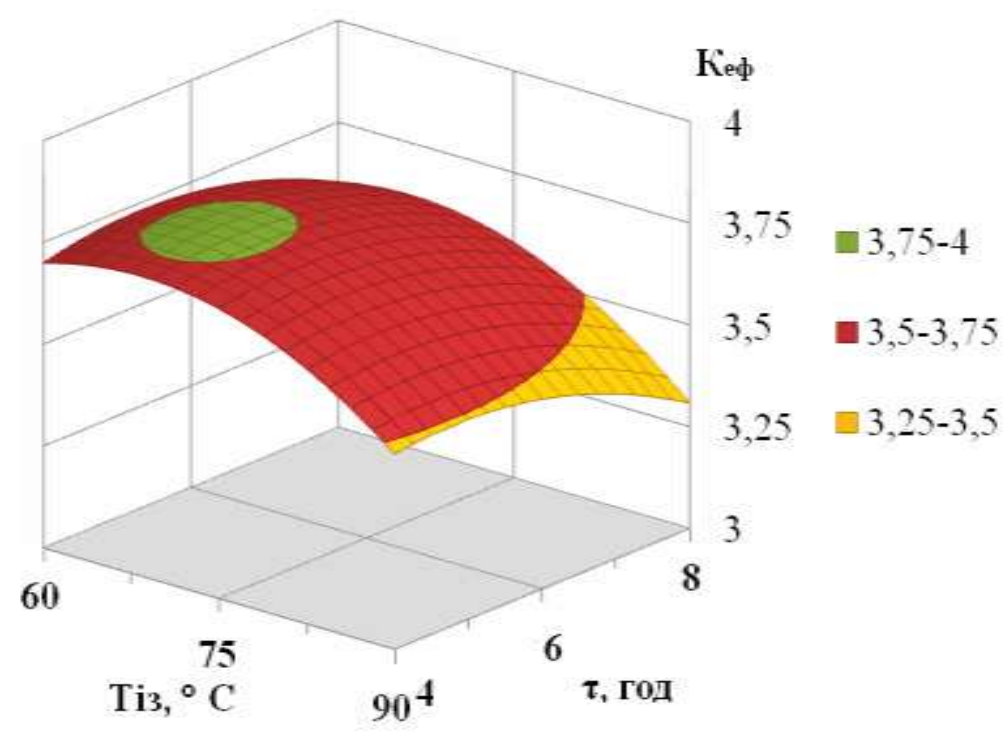

Рис. 3. Вплив технологічних факторів на ефективність використання клінкеру в бетонах на основі золовмісних ЦНВ

Цікавим $є$ той факт, що збільшення тривалості ізотермічної витримки зменшує показник навіть більше, ніж підвищення іiі температури. Тому можна вважати, що низькотемпературні режими ТВО $\epsilon$ не тільки менш енергоємними, але й більш ефективними для бетонів на золовмісних ЦНВ.

\section{Висновки}

1. Установлено, що бетони на основі золовмісних цементів низької водопотреби, які пройшли тепловологісну обробку, 
характеризуються міцністю, яка на 7...25 \% вища від міцності зразків, які тверділи за нормальних умов. Теплова обробка в температурному інтервалі $60 \ldots 75^{\circ} \mathrm{C}$ супроводжує зростання міцності на $7 \ldots 12 \%$ в порівнянні 3 нормальним режимом твердіння, а в температурному інтервалі $75 \ldots 90{ }^{\circ} \mathrm{C}$ - на $10 \ldots 24 \%$ при різній тривалості ізотермічної витримки.

2. Серед параметрів теплової обробки вплив іi температури на міцність безпосередньо після ТВО є більш значним, ніж тривалість теплової обробки. Однак збільшення тривалості ізотермічного витримування дозволяє компенсувати зниження температури без підвищення сумарних енергозатрат. Через 4 год після ТВО для досліджених бетонів навіть при мінімальних iii параметрах досягається відпускна міцність більше $90 \%$ від марочної.

3. У віці 28 діб вплив параметрів TВО на міцність нівелюється. Використання в бетоні золовмісних ЦНВ дозволяє досягти марочної міцності пропареного бетону $56 \ldots 60,7 \mathrm{MПа} \mathrm{при} \mathrm{витраті}$ в'яжучого $320 \mathrm{\kappa г} / \mathrm{m}^{3}$ та 77,4...82,1 МПа при витраті в'яжучого $520 \mathrm{\kappa г} / \mathrm{m}^{3}$.

4. Одним із критеріїв ефективності використання портландцементного клінкеру в бетоні $\epsilon$ відношення його витрати на $1 \mathrm{~m}^{3}$ до досягнутої міцності бетону. Цей же показник можна використати для оцінки ефективності теплової обробки, якщо враховувати міцність після ТВО. Обробка отриманих даних свідчить про те, що для підвищення ефективності ТВО доцільне збільшення обох ¥ii параметрів - тривалості та температури і визначальним фактором при цьому стають можливі енергозатрати.

5. Для виробів, до яких ставляться підвищені вимоги за довговічністю, доцільною $є$ ТВО бетонів на основі золовмісних ЦНВ при температурі не більше $60^{\circ} \mathrm{C} \quad 3$ тривалістю ізотермічної витримки 4...6 год.

\section{Сиисок літератури}

1. Цементы низкой водопотребности: новые результаты и перспективы [Текст] / Б.Э. Юдович [и др.] // Цемент и его применение. - 2006. - Июль-август. - С. 80-84.

2. Високоміцні бетони на цементах низької водопотреби з використанням пиловидних відходів промисловості [Текст] / Л.Й. Дворкін [та ін.]. // Будівельні матеріали, вироби та санітарна техніка: наук.-техн. зб.; Український науково-дослідний і проектноконструкторський інститут будівельних матеріалів та виробів «НДІБМВ». - К.: Знання, 2012. - Вип. 43. - С. 73-80. $768 \mathrm{c}$.

3. Батраков, В.Г. Модифицированные бетоны. Теория и практика [Текст]. - М.: 1998. -

4. Дворкін, Л.Й. Розв'язування будівельно-технологічних задач методами математичного планування експерименту [Текст] / Л.Й. Дворкін, О.Л. Дворкін, В.В. Житковський. - Рівне: НУВГП, 2011. - 174 с.

5. Дворкин, Л.И. Снижение расхода цемента и топлива в производстве сборного железобетона [Текст]. - К.: Вища шк., 1985.

Ключові слова: цементи низької водопотреби, зола-виносу, тепловологісна обробка, довговічність бетону. 


\section{Анотаціï}

Наведені результати дослідження впливу режимів тепловологісної обробки на міцність бетонів на основі золовмісних цементів низької водопотреби. Встановлено оптимальні параметри режимів тепловологісної обробки.

Приведены результаты исследования влияния режимов тепловлажностной обработки на прочность бетонов на основе золосодержащих цементов низкой водопотребности. Установлены оптимальные параметры режимов тепловлажностной обработки.

It is shown the findings of an investigation into curing conditions influence on the concrete strength, based on the cements of law water demand, using fly-ash. Optimal curing conditions parameters have been determined. 